\title{
Recent Advances in the Application of Non Thermal Methods for the Prevention of Salmonella in Foods
}

\author{
Shilpi Gupta and Nissreen Abu-Ghannam \\ School of Food Science and Environmental Health \\ College of Sciences and Health \\ Dublin Institute of Technology, Dublin \\ Ireland
}

\section{Introduction}

Food-borne illness as a result of consumption of foods contaminated with pathogenic bacteria is a world-wide concern. The presence and subsequent growth of micro-organisms in food in addition to improper storage not only results in spoilage but also in a reduction of food quality. The microbiological safety in ready to eat products is a cause of big concern not only for the consumers and food industries but also for the regulatory agencies. The number of documented outbreaks of foodborne diseases has increased in the last decade with Salmonella spp., Listeria monocytogenes and Escherichia coli being responsible for the largest number of outbreaks and deaths.

The European Food Safety Authority (EFSA) reported Salmonella to be the most common cause of food-borne outbreaks in the EU (EFSA, 2009). As high as 50,000 and 35,000 people were reported to be suffering from salmonellosis in the Netherlands during 1999-2000 and 2002, respectively (Bouwknegt et al., 2003). The symptoms include diarrhoea, vomiting, nausea, abdominal pain and fever. Salmonella enterica Typhimurium and Salmonella enterica Enteritidis are the most frequently isolated serovars in the EU which are responsible for diarrhoea and fever (EFSA-ECDC, 2007). Some strains of Salmonella such as S. Senftenberg are more heat resistant than other strains. Even in the United States, Salmonella is considered to be one of the most prevalent bacteria amongst the foodborne pathogens, causing an estimated 1.6 million foodborne illnesses with annual cost of $\sim \$ 14$ billion. Salmonella Typhimurium has been implicated in the US as the major causative agent for food borne salmonellosis.

\section{Salmonella}

Salmonella is a gram negative, non-spore forming bacilli belonging to the family Enterobacteriaceae and is one of the most prominent food pathogenic bacteria. This pathogen has the ability to grow at a wide range of temperatures $\left(8-45^{\circ} \mathrm{C}\right), \mathrm{pH}(4$ to 9$)$ and foods with high moisture content (thus high water activity). Since the organism is heat sensitive, it is more prevalent in raw and under-cooked foods. In general, consumption of 
contaminated foods such as raw or under-cooked eggs, meat, poultry or even dairy products can act as vehicles for salmonellosis in humans. Because of the ability of Salmonella cells to exist under dormant conditions and regain active growth phase when favourable conditions return, it also has the ability to survive in dry products. As fresh cut fruits lack any skin barrier they are also likely to be contaminated by Salmonella. Storage of raw or pasteurized foods under refrigerated conditions or with treatments that reduce $\mathrm{pH}$ can help to increase the shelf life by retarding or avoiding the growth but certain strains of Salmonella have been reported to survive even under chilling conditions. It is now evident that these conditions cannot stop the chromosomal replication and are only bacteriostatic in nature (Tahergorabi et al., 2011). Risco (2009) reported survival of Salmonella inoculated into chicken nuggets during 16 weeks at $-20^{\circ} \mathrm{C}$. This further adds to the problems that can arise by the consumption of ready to eat frozen products that are just pre-warmed in a microwave prior to consumption.

Although any person can contract food poisoning due to Salmonella, the disease can be more serious in infants, elderly and people with weak immune system. Treatment with antibiotics becomes essential for the eradication of this bacterial species. However, excessive use of antibiotics has made several strains to develop resistance against such drugs resulting in increased prevalence of these resistant strains in humans and animals. In order to minimize its presence in foods, synthetic antimicrobial agents such as sodium benzoate and sodium nitrite were used. However, these are also losing popularity due to consumer demand for food products with natural preservatives. Thermal processing is the most efficient way for eliminating Salmonella from foods. However, consumer's demand for minimally processed foods in addition to the negative effect of heat on nutritional properties of foods is making this technology less popular in the food industry. Novel remedies for safe and efficient removal of this bacterium from foods are becoming vital. Nowadays, non thermal techniques such as the addition of naturally occurring compounds having antibacterial activity, the use of high pressure carbon dioxide (HPCD), use of electrolysed water, high intensity pulsed electric field (PEF) or irraditation are increasingly gaining attention as a means of food preservation. In addition, it is imperative for the non thermal applications to have similar or higher inactivation as compared to the traditional heat treatments. According to US-FDA guidelines, the main requirement is to reduce the pathogen load by 5 logs (FDA, 2001). The major advantage of these non-thermal technologies (table 1) is that they are environmentally friendly and act at ambient or sub-lethal temperatures resulting in minimal impact on color, flavor and nutritional quality of foods. These techniques help in retaining the "fresh-like" characteristics of food and may also help to preserve functionalities.

However, the use of essential oils and other plant extracts is often limited by organoleptical criteria. Moreover, high pressures can cause cell wall breakdown and result in loss of cell turgidity. Thus, under these conditions, it might be necessary to combine two or more technologies in order to achieve the desired preservative effect. The technique of combination or "hurdle technology" is slowly becoming eminent. Thus, the use of natural antimicrobials along with pulsed electric field, ozone or super critical carbon dioxide can be used to curtail the growth of Salmonella with a minimal effect on the sensory characteristics such as flavor. 


\begin{tabular}{|c|c|c|}
\hline & Advantages & Limitations \\
\hline Irradiation & $\begin{array}{l}\text { Effective for several foods } \\
\text { Many different sources available } \\
\text { (Gamma rays, electron beam) }\end{array}$ & $\begin{array}{l}\text { Limited public acceptance } \\
\text { Lipid oxidation of meat products }\end{array}$ \\
\hline UV radiation & $\begin{array}{l}\text { No chemicals are used } \\
\text { Non-heat related method } \\
\text { Lesser changes in quality attributes } \\
\text { of food }\end{array}$ & $\begin{array}{l}\text { Long term exposure can be } \\
\text { harmful to the industry workers }\end{array}$ \\
\hline HPP & $\begin{array}{l}\text { Independent of the shape of food } \\
\text { Can be used for both solid and } \\
\text { liquid samples. }\end{array}$ & $\begin{array}{l}\text { Changes in quality of food has } \\
\text { been observed }\end{array}$ \\
\hline HPCD & $\begin{array}{l}\text { Can be used in a batch or } \\
\text { continuous process } \\
\mathrm{CO}_{2} \text { is GRAS, nonflammable and } \\
\text { non-toxic }\end{array}$ & $\begin{array}{l}\text { Not very successful for solid } \\
\text { foods } \\
\text { Commercial application is still } \\
\text { not a success }\end{array}$ \\
\hline PEF & $\begin{array}{l}\text { Pulse applied for a short period so } \\
\text { no generation of heat } \\
\text { Less usage of energy }\end{array}$ & $\begin{array}{l}\text { Cannot be applied to foods } \\
\text { which cannot withstand high } \\
\text { fields } \\
\text { Cannot be applied to foods that } \\
\text { form bubbles }\end{array}$ \\
\hline $\begin{array}{l}\text { Natural } \\
\text { antimicrobials }\end{array}$ & $\begin{array}{l}\text { Natural "green" preservatives } \\
\text { Have "GRAS" status }\end{array}$ & $\begin{array}{l}\text { Can have a negative effect on the } \\
\text { sensory properties of foods }\end{array}$ \\
\hline
\end{tabular}

Table 1. Limitations and advantages of non thermal processing techniques

\section{Thermal processing}

Heating of food is the most common and effective method for eliminating pathogens. Thermal pasteurization, involving the reduction or inactivation of micro-organisms, was traditionally the most common method for the production of microbiologically safe food products. The method involves generation of heat outside the food which gets transferred into the food through conduction or convection. Although the method is inexpensive, preservative free and environmental friendly, it does result in undesirable changes related to the nutritional and organoleptical properties of foods. At the same time, the content or bioavailability of some bioactive compounds such as ascorbic acid, phenolic compounds or carotenoids may be severely diminished. The case becomes even worse if the food product is heat sensitive. Nonetheless the extent of destruction depends on the temperature used for processing in addition to the time for which it is applied. In order to circumvent the shortcomings of thermal processing, several non-thermal methods such as the use of radiation, high pressure processing and natural antimicrobials are receiving considerable attention (table 2). 


\begin{tabular}{|c|c|c|c|c|c|}
\hline Food Product & Strain & Condition & Reduction & Reference & Technique \\
\hline Chicken meat & S. Typhimurium & $\begin{array}{l}13.7 \mathrm{MPa}, \\
35^{\circ} \mathrm{C}, 2 \mathrm{~h}\end{array}$ & $94-98 \%$ & Wei et al., 1991 & hpcd \\
\hline \begin{tabular}{|l|} 
Beef \\
Trimmings
\end{tabular} & Salmonella spp. & \begin{tabular}{c|}
$10.3 \mathrm{MPa}$, \\
$36^{\circ} \mathrm{C}, 15 \mathrm{~min}$
\end{tabular} & $0.83 \log$ & Meurehg, 2006 & hpcd \\
\hline Ground beef & Salmonella spp. & $\begin{array}{c}10.3 \mathrm{MPa}, \\
36^{\circ} \mathrm{C}, 15 \mathrm{~min}\end{array}$ & $1.23 \log$ & Meurehg, 2006 & hpcd \\
\hline $\begin{array}{l}\text { Physiological } \\
\text { saline }\end{array}$ & S. Typhimurium & $\begin{array}{c}6 \mathrm{MPa}, 35^{\circ} \mathrm{C}, \\
15 \mathrm{~min}\end{array}$ & $7 \log$ & \begin{tabular}{|l|} 
Erkmen and \\
Karaman 2001
\end{tabular} & hpcd \\
\hline Orange juice & S. Typhimurium & $\begin{array}{c}38 \mathrm{MPa}, 25^{\circ} \mathrm{C} \\
10 \mathrm{~min}\end{array}$ & $6 \log$ & $\begin{array}{l}\text { Kincal et al., } \\
2005\end{array}$ & hpcd \\
\hline Melon juice & S. Enteritidis & $\begin{array}{c}2000 \mu \text { s and } \\
100 \mathrm{~Hz}\end{array}$ & $4.27 \log$ & $\begin{array}{l}\text { Mosqueda- } \\
\text { Melgar et al., } \\
2007\end{array}$ & PEF \\
\hline $\begin{array}{l}\text { Watermelon } \\
\text { juice }\end{array}$ & S. Enteritidis & $\begin{array}{c}1250 \mu \text { s and } \\
175 \mathrm{~Hz}\end{array}$ & $3.75 \log$ & $\begin{array}{l}\text { Mosqueda- } \\
\text { Melgar et al., } \\
2007 \\
\end{array}$ & PEF \\
\hline Orange juice & S. Typhimurium & $\begin{array}{c}90 \mathrm{kV} / \mathrm{cm} \text { and } \\
55^{\circ} \mathrm{C}\end{array}$ & $5.0 \log$ & $\begin{array}{l}\text { Liang et al., } \\
(2002)\end{array}$ & PEF \\
\hline UHT Milk & Salmonella spp. & $\begin{array}{c}600 \mathrm{MPa} \text { for } 10 \\
\text { min and } \\
21.5^{\circ} \mathrm{C}\end{array}$ & $6.5-8.2 \log$ & Chen et al., 2006 & $\mathrm{HPP}$ \\
\hline Orange juice & Salmonella spp. & $\begin{array}{c}600 \mathrm{MPa} \text { and } \\
20^{\circ} \mathrm{C} \\
\end{array}$ & $7 \log$ & Bull et al., 2004 & HPP \\
\hline Sliced Ham & S. Typhimurium & 2 kGy & 3.78 & Song et al., 2011 & $\begin{array}{c}\text { Electron } \\
\text { beam }\end{array}$ \\
\hline Sliced Ham & S. Typhimurium & $8000 \mathrm{~J} / \mathrm{m}^{2}$ & $2.02 \log s$ & Chun et al., 2009 & UV-C \\
\hline
\end{tabular}

Table 2. Inactivation of Salmonella spp. achieved by application of non-thermal techniques in foods

\section{Non thermal approaches}

\subsection{Application of radiation}

\subsubsection{Irradiation}

The use of ionizing radiation as a means of food preservation is being extensively researched and is approved in many countries such as the United States, France, Netherlands and Canada. The use of radiation dose up to 7 kiloGray (kGy) has been sanctioned by WHO as safe. The critical target of ionizing radiation is the bacterial DNA. Gamma rays, X-rays and electron beam are the most common types of ionizing radiation. Gamma radiation is generated using radioactive isotopes such as cobalt-60 or Cesium-137 (FDA approved) whereas for electron beam high speed electrons are generated using electricity. Generation of X-rays involves interposition of a metal target between the food and the electron beam. The choice of use between e-beam and X-ray is typically made as an exchange between efficiency and product penetration depth. Unlike gamma radiation, the 
processing time using electron beam is very short and the technique does not produce radioactive waste. The effect of both techniques on the quality is minimal as no heat is generated during the process. However, electron beam can penetrate only up to $8 \mathrm{~cm}$ in foods which is its major limitation. Nonetheless both these techniques are being studied for eliminating Salmonella. Irradiation in the range of 2-3 kGy has been used for the elimination of Salmonella in meat products. Park et al. (2010) reported lower total aerobic counts in gamma rays treated beef sausage patties as compared to electron beam treated samples. Reduction of 3.78 and 2.04 logs has been reported using electron beam irradiation (2 kGy) for S. Typhimurium inoculated in sliced ham (Song et al., 2011) and powdered weaning foods (Hong et al., 2008), respectively whereas Martins et al., (2004) reported a 4 log reduction in a cocktail of Salmonella strains using $1.7 \mathrm{kGy}$ in watercress thereby showing the applicability of gamma radiation in salad vegetables. Application of $3 \mathrm{kGy}$ electron beam resulted in a reduction of 6.75 and $4.85 \operatorname{logs}$ of $S$. Tennessee and $S$. Typhimurium inoculated in Peanut butter (Hvizdzak et al., 2010). In contrast, irradiation by electron beam was found to be an unacceptable method for destroying Salmonella on raw almonds (Prakash et al., 2010). A dose of $5 \mathrm{kGy}$ was reported to be required for achieving a $4 \log$ reduction whereas radiation intensity higher than $2.98 \mathrm{kGy}$ induced significant sensory changes in raw almonds (Prakash et al., 2010). Mahmoud (2010) reported 3.7 logs reduction in S. enterica per tomato upon the application of $0.75 \mathrm{kGy} X$-rays. Increasing the dose to more than $1 \mathrm{kGy}$ resulted in more than 5 logs reduction. X-ray has shown to result in more than $6 \operatorname{logs}$ reduction in ready to eat shrimps (Mahmoud, 2009) and spinach leaves and shredded iceberg lettuce (Mahmoud et al., 2010). However, several adverse effects (lipid oxidation, textural degradation) caused by ionizing radiation have prevented this technology from being extended. Especially, lipid oxidation of meat products by irradiation is the most important factor for quality decline. An increase in the off-odors of irradiated ground pork and pork chops upon refrigerated storage were observed (Ohene-Adjei et al., 2004). The negative effects of gamma radiation on the appearance and color of chicken breasts, pork loin and beef loin, has also been reported (Kim et al., 2002). Additionally just like other inactivation techniques, $S$. Typhimurium has been reported to develop resistance against the radiation if the cells are repeatedly processed with electron beam at sub-lethal doses (Tesfai et al., 2011). Although irradiation has a high potential to be used for food preservation, its use is limited by an uncorroborated view that irradiated foods are not well accepted by the public as safe and desirable.

\subsubsection{Ultravoilet radiation}

Irradiation using non-ionizing rays, especially ultraviolet (UV)-C (wavelengths of 220-300 nm with $90 \%$ emission at $253.7 \mathrm{~nm}$ ) has been approved as a non thermal method by the U.S. Food and Drug Administration (FDA) for surface sterilization (US Food and Drug Administration (2007)). This technique has been used extensively to decontaminate food surfaces directly or other materials which come in contact with food surfaces. The main industrial application of UV is its use in disinfection of drinking water. The mechanism of action of UV light involves the interruption of bacterial replication due to the formation of thymine dimers in the bacterial chromosome either killing them or making them unable to reproduce.

Chun et al., (2009) reported a reduction of 2.02 logs of $S$. Typhimurium in sliced ham upon the application of $8000 \mathrm{~J} / \mathrm{m}^{2}$ of UV-C whereas in the case of chicken breasts a reduction of only 1.19 logs were observed upon the application of $5 \mathrm{~kJ} / \mathrm{m}^{2} \mathrm{UV}-\mathrm{C}$ radiation (Chun et al., 
2010). At the same time, storage of UV-C treated chicken breasts resulted in an increase in the TBARS values and a negligible change in the Hunter $L$, $a$ and $b$ values for the product. The effects of UV-C on the quality attributes and decontamination efficiency against Salmonella Enteritidis were evaluated in different egg fractions (de Souza and Fernández, 2011). In terms of quality attributes, UV-C did not affect the viscosity and the $\mathrm{pH}$ however, browning due to maillard reaction was detectable in egg yolk and whole egg at low UV-C doses. The TBARS value was not significantly different to untreated samples. At the same time, a reduction of 5.3, 3.3 and $3.8 \log$ was achieved under dynamic conditions $\left(9.22 \mathrm{~J} / \mathrm{cm}^{2}\right.$, $39 \mathrm{~min}$ ) in egg white, egg yolk and whole egg, respectively.

The main drawback of UV irradiation is that it is a surface sterilization method. The efficiency of the treatment will strongly depend on the actual location of the bacterial contaminant as well as the composition, surface topography and transmissivity of the food (Allende et al., 2006). Moreover, the penetration of UV in liquid foods will strongly depend on the characteristics of the liquid product. The presence of solid particles and other components can seriously hinder the penetration. In addition the actual physical arrangement, power and wavelength of the UV source will also play a significant role. Besides, care has to be taken while using short wave UV regarding the damage that it can cause to human eyes in addition to being a cause of skin cancers and burns in humans upon excessive exposure.

\subsection{Application of pressure}

\subsubsection{High pressure processing (HPP)}

High pressure processing (HPP) is a food processing method involving the application of pressure throughout the food. The technique is independent of the shape of food and can be used for both solid and liquid samples. Pressures in the range of 100-800 MPa are generally applied with temperatures ranging from $0-100{ }^{\circ} \mathrm{C}$. The main target for HPP is the bacterial cytoplasmic membrane. In addition to the loss of solute, enzyme inactivation and protein coagulation might also occur as a result of excess pressure. HPP technique has been used for reducing or eliminating Salmonella in foods or culture media. Reduction of 6.5-8.2 logs in Salmonella inoculated in UHT whole milk was achieved at a pressure of $600 \mathrm{MPa}$ for $10 \mathrm{~min}$ and $21.5^{\circ} \mathrm{C}$ (Chen et al., 2006). Several instances regarding the growth of Salmonella spp. on the surface of tomatoes have been reported. HPP has been applied for the removal of this bacterium from the tomatoes surface. Application of pressures in the range of $350-550 \mathrm{MPa}$ has been reported to result in 0.46-3.67 log reduction in S. enterica serovar Braenderup inoculated on diced and whole tomatoes (Maitland et al., 2011). Exposure to a pressure of $550 \mathrm{MPa}$ for $2 \mathrm{~min}$ resulted in a reduction of several S. enterica serovars (Baildon, Gaminara, Michigan and Typhimurium) in the range of $4 \mathrm{log} \mathrm{cfu} / \mathrm{ml}$ or greater for broth, water and apple juice (Whitney et al., 2007). Time did not seem to be an important factor when HPP was applied in a chicken meat model system. Treatment at $400 \mathrm{MPa}$ for 2 min and $20{ }^{\circ} \mathrm{C}$ resulted in an inactivation between 3.26 and $4.35 \mathrm{log}$ in a chicken meat model system (Escriu and Mor-Mur, 2009). The applicability of HPP as a preservation method against Salmonella has also been evaluated for products with lower water activity such as raw almonds. Goodridge et al. (2006) studied the effect of continuous and oscillatory HPP treatment on the viability of two Salmonella Enteriditis strains (FDA and PT30) inoculated onto raw almonds. Continuous pressurization of raw almonds resulted in less than one log reduction whereas the oscillatory process provided 1.27 and $1.16 \log$ reduction for FDA and PT30 strains, respectively. However, a reduction of 3.37 logs was achieved when the almonds were 
directly suspended in water and then given the treatment. The effect was attributed to the fact that low water activity provided a protective effect to the bacterial cells. Application of $\mathrm{HPP}$ to orange juice resulted in 7-log inactivation of Salmonella at $600 \mathrm{MPa}$ and $20^{\circ} \mathrm{C}$ (Bull et al., 2004) and $615 \mathrm{MPa}$ and $15^{\circ} \mathrm{C}$ (Teo et al., 2001) for $60 \mathrm{~s}$. At the same time, HPP was reported not to have any significant effect on the quality parameters of orange juice such as titratable acid content, ${ }^{\circ}$ Brix, viscosity, alcohol insoluble acids, color, ascorbic acid and $\beta$ carotene concentrations (Bull et al., 2004).

However, the application of high pressure at high temperatures may result in undesirable changes in the quality of many foods. Moreover, in the case of meat products, high pressure can increase the susceptibility of meat products to attack by oxygen thus resulting in increased lipid oxidation. For instance, Ma et al. (2007) reported almost 5-fold increase in TBARS values after 7 days storage at $4{ }^{\circ} \mathrm{C}$ in beef exposed to a pressure $\geq 400 \mathrm{MPa}$. In other studies, pressures higher than 300 or $400 \mathrm{MPa}$ (at ambient temperatures) caused increased rate of oxidation in pork (Cheah and Ledward, 1996) and cod muscles (Angsupanich and Ledward, 1998), respectively. McArdle et al. (2011) reported detrimental effect of HPP at $600 \mathrm{MPa}$ on texture, oxidation and water binding properties of beef. However lower TBARS and cook loss for beef processed by HPP were obtained as compared to raw or conventional heat processed samples. Besides, HPP carried out at high temperatures can cause cell wall breakdown and result in loss of cell turgidity. In addition, large-scale industrial application will only be possible if the technique becomes economical. The treatment time and the pressures applied are the major factors involved in deciding the cost and in achieving the desirable microbial inactivation. Hence, it is important to optimize conditions wherein minimal pressure is applied for the shortest time so that a food product with a reasonable cost is obtained.

\subsubsection{High pressure carbon dioxide (HPCD)}

High pressure carbon dioxide (HPCD) is another upcoming treatment that is being extensively used as a non-thermal technique for food pasteurization. The process is not only environmentally friendly due to the non-toxic nature of carbon dioxide but also involves application of lower $\mathrm{CO}_{2}$ pressure as compared to those employed for HPP. The use of lower pressures makes this technique an energy-saving process. The major factor involved in the destruction is $\mathrm{CO}_{2}$ although pressure helps in greater penetration of $\mathrm{CO}_{2}$ in the cells. Lethality imparted by pressurized $\mathrm{CO}_{2}$ is a result of disassociation of $\mathrm{CO}_{2}$ (in foods with high water content) into reactive ions such as carbonates $\left(\mathrm{CO}_{3}{ }^{2-}\right)$, bicarbonates $\left(\mathrm{HCO}_{3}^{-}\right)$and hydrogen $\left(\mathrm{H}^{+}\right)$. These reactive ionic species can then have an effect on the permeability of the cell membrane and properties of cell constituents. In addition, generation of carbonic acid $\left(\mathrm{H}_{2} \mathrm{CO}_{3}\right)$ in the water present in food products further results in a reduction in the $\mathrm{pH}$ of the food products enhancing the penetration of $\mathrm{CO}_{2}$ (Wei et al., 1991).

Studies involving the use of HPCD for the inactivation of $S$. Typhimurium (Kim et al., 2007; Erkmen and Karaman, 2001; Erkmen 2000; Wei et al., 1991) have clearly reported the microbial strain, pressure applied, $\mathrm{pH}$ of the medium, type of medium and temperature to be important factors for the inactivation. $S$. Typhimurium in orange juice was effectively reduced by 5-6 logs when subjected to continuous dense phase carbon dioxide (DPCD) for $10 \mathrm{~min}$ at $21-107 \mathrm{MPa}$ and $25^{\circ} \mathrm{C}$ (Kincal et al., 2005) whereas in another study reduction as high as 8 logs was achieved when the growth media was changed to physiological saline (PS) or phosphate buffer solution (Kim et al., 2007). Kim et al. (2007) also analyzed the structural changes in $S$. Typhimurium cells upon the application of super-critical $\mathrm{CO}_{2}$. A 
complete loss of colony forming activity was observed for the treated cells with a formation of veins and small vesicles on the surface. TEM images showed the inner areas to be highly disrupted accompanied by a membrane deformation. In addition, shrinking and uneven dispersion of cytoplasmic materials was also observed (Figure 1). Liao et al. (2010) obtained a remarkable reduction of $5 \operatorname{logs}$ for $S$. Typhimurium when carrot juice was subjected to DPCD treatment. Both temperature and pressure had a noticeable effect as the inactivation was enhanced with increasing pressure at a constant temperature or increasing temperature at a constant pressure. In contrast, inactivation of $S$. Typhimurium in PS or PS containing $10 \%$ brain-heart infusion (PS-BHI) broth was completed in $35 \mathrm{~min}$ in PS whereas it took 140 min in the case of PS-BHI (Erkmen, 2000). Besides, the previous study reported the presence of two phases during the destruction characterized by a slow rate of reduction in the cell number which increased sharply at the later stage. Erkmen and Karaman (2001) observed that the exposure time required to achieve the same level of Salmonella inactivation was drastically reduced as the pressure during the inactivation increased. Complete inactivation of Salmonella was reported in egg yolk, 94-98\% in chicken meat strips and limited inactivation in whole egg at a pressure of $13.7 \mathrm{MPa}$ at $35^{\circ} \mathrm{C}$ for $2 \mathrm{~h}$ (Wei et al., 1991). The variation in the results clearly indicates the complex nature of food systems. A treatment of $14 \mathrm{MPa}$ at $45^{\circ} \mathrm{C}$ for $40 \mathrm{~min}$ resulted in a $34.48 \%$ and $32.74 \%$ reduction for $S$. Typhimurium in soy sauce and hot-pepper paste marinated pork products, respectively (Choi et al., 2009a). However, the technique is more suitable for liquid foods as the diffusion of $\mathrm{CO}_{2}$ into solid samples becomes a limitation due to the absence of agitation in solid foods. Also, high concentrations of $\mathrm{CO}_{2}$ can cause darkening of color of certain animal products due to the formation of metmyoglobin. Due to the complex nature of foods conflicting results are available on the effect of HPCD on sensory, chemical and physical properties of foods. In spite of the potential advantages of HPCD more research is needed to monitor and quantify sensory and chemical characteristics of foods undergoing this preservation technique.

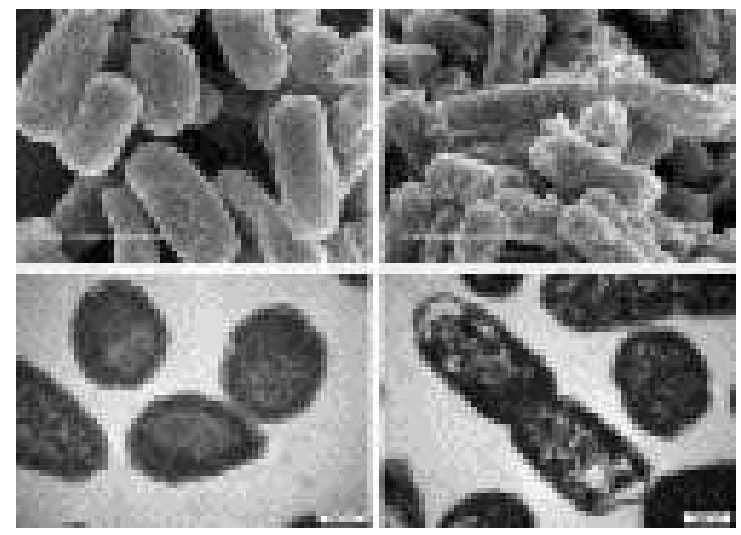

Fig. 1. Scanning electron micrograph (upper; magnification: 20,000) and Transmission electron micrograph (lower; magnification: 50,000) images of $S$. Typhimurium cells (left: untreated; right: treated) upon application of super critical carbon dioxide at $35^{\circ} \mathrm{C}$ and 100 bar for $30 \mathrm{~min}$ (Kim et al., 2007) 


\subsection{Pulsed electric field (PEF)}

Pulsed electric field (PEF) is another non-thermal technology that can be used to inactivate bacterial cells at ambient temperatures. The process involves placing the food material between two electrodes and passing pulses of high electric field $(1-50 \mathrm{kV} / \mathrm{cm})$ strengths. Since the pulses are applied for short durations $(2 \mu \mathrm{s}$ to $1 \mathrm{~ms})$ the negative impact on food quality due to heat processing is highly diminished (Barbosa-Cánovas et al., 2001). The technique is more suitable for liquid or semi-liquid foods which can be easily pumped. It can be used to increase the shelf life of soups, milk, whole liquid eggs and fruit juices. PEF as a non-thermal preservation method has been implemented by Genesis Juices, Oregon, USA. The application of electric field results in cellular death due to generation of pores (electroporation) in the bacterial cell membrane without having an effect on enzymes or proteins present in foods (Wouters et al., 2001). The effectiveness of the technique will strongly depend on the treatment time, electric field strength and specific energy of the pulses. For instance, Monfort et al., (2010) achieved an inactivation of 4 log for Salmonella Typhimurium when $45 \mathrm{kV} / \mathrm{cm}$ of electric field was applied for $30 \mu \mathrm{s}$. Higher number of pulses and electric field was reported to be a stronger factor for reducing the number of $S$. Typhimurium population in orange juice (Liang et al., 2002) whereas in another study on melon and water melon juices, treatment time was found be a more important factor (Mosqueda-Melgar et al., 2007). Treatment of watermelon and melon juice with PEF resulted in a reduction of $4.27 \log$ (at $2000 \mu \mathrm{s}$ and $100 \mathrm{~Hz}$ ) and $3.75 \log$ (at $1250 \mu \mathrm{s}$ and $175 \mathrm{~Hz}$ ) of $S$. Enteritidis, respectively (Mosqueda-Melgar et al., 2007). In contrast, Liang et al. (2002) reported a $5 \log$ reduction of $S$. Typhimurium in orange juice exposed to a PEF of $90 \mathrm{kV} / \mathrm{cm}$ at a temperature of $55{ }^{\circ} \mathrm{C}$. However, the higher reduction could be a result of combination of higher acidity of orange juice in addition to relatively higher temperature and high intensity of the PEF applied. Although the technique is useful, inactivation has only been achieved in the range of 3-4 logs.

\subsection{Natural antimicrobials}

Since ancient times, spices and herbs have been used for preventing food spoilage and deterioration, and also for extending food shelf life. The antimicrobial effect of these components is a result of an increase in the permeability of the cytoplasmic membrane which leads to the loss of cellular constituents. At the same time, plant secondary metabolites such as essential oils and natural plant extracts have also been reported to have antibacterial, antifungal and anti-insecticidal properties. Extracts from capsicum, seaweeds and green tea have been found to inhibit the growth of Salmonella spp. in-vitro. Studies are also available wherein inhibitory effect of plant extracts was evaluated against Salmonella inoculated in minced beef, salad vegetables, fresh cut apples and minced sheep meat.

\subsubsection{Extracts from vegetables}

Vegetable extracts have shown a good potential when applied under laboratory conditions in culture media. For instance, application of $6 \%$ seaweed extract was shown to result in complete inhibition of S. abony whereas 3\% extract resulted in 93\% inhibition (Gupta et al., 2011). In contrast, 2.8\% methanolic extract from Irish York cabbage was shown to result in only $64 \%$ inhibition of S. abony (Jaiswal et al., 2011). Xu et al. (2007) reported a minimal inhibitory concentration (MIC) of $15 \mu$ l of grapefruit seed extract to 
inhibit Salmonella. Careaga et al. (2003) reported that a minimum concentration of $1.5 \mathrm{ml}$ of capsicum extract per $100 \mathrm{~g}$ of meat was needed in order to prevent the growth of $S$. Typhimurium inoculated in minced beef. Karapinar and Sengun (2007) evaluated the antimicrobial activity of koruk (unripe grape-Vitis vinifera) juice against $S$. Typhimurium on cucumber and parsley samples which resulted in 1-1.5 log reduction upon immediate contact with korak juice and the reduction increased as the time of exposure of the vegetables to the juice increased.

The antimicrobial efficacy of plant extracts has been attributed to the presence of phenolic compounds, quinones, alkaloids, flavanols/flavonoids and lectins. Solubility of the extract in the food systems and the $\mathrm{pH}$ of the extract are important factors determining their efficacy in foods. Mechanism of action of these phenolic compounds involves alteration in the cell morphology which results in a disruption of the cytoplasmic membrane and leakage of cell constituents. Although the use of vegetable extracts for controlling the growth of Salmonella is promising the actual application in foods is in its budding stage.

\subsubsection{Extracts of herbs and spices}

In addition to providing flavor and fragrance, spices and herbs have also antimicrobial potential and thus can be used for preventing food deterioration and shelf life extension. Sumac, rosemary, sage, basil and ginger are some of the spices commonly being used for imparting antimicrobial effects on food. The flower, buds, leaf, stem or bark of these plants contains aromatic oily liquid which is the essential oil (EO). These EO are rich in phytochemicals such as terpenoids, polyphenols, flavonoids, antocyanin and organic acids which are responsible for the antimicrobial activity. Compounds such as carvacrol, citral, thymol, eugenol and citric acid have been shown to inhibit the growth of Salmonella. Eugenol has been reported to strongly inhibit the growth of Listeria monocytogenes, Salmonella Enteritidis, Escherichia coli and Staphylococcus aureus. Carvacrol and thymol are reported to be the principal constituents of EO of certain herbs. Burt et al. (2007) evaluated the antimicrobial activity of carvacrol vapour against $S$. Enteritidis on pieces of raw chicken. UV sterilized chicken pieces treated with carvacrol vapour $(2 \mu \mathrm{l})$ showed reduced viable numbers of salmonellae at 4,20 and $37^{\circ} \mathrm{C}$ and a concentration of $4 \mu \mathrm{l}$ resulted in a complete elimination of all viable cells in a minimum of $3 \mathrm{~h}$ at $37^{\circ} \mathrm{C}$. Govaris et al. (2010) studied the antimicrobial effect of oregano EO, nisin and their combination against $S$. Enteritidis in minced sheep meat during refrigerated storage $\left(4\right.$ or $\left.10{ }^{\circ} \mathrm{C}\right)$ for 12 days. Addition of nisin, at 500 or $1000 \mathrm{IU} / \mathrm{g}$, proved insufficient to inhibit $S$. Enteritidis. The addition of oregano EO at $0.9 \%$ caused the population of $S$. Enteritidis to be maintained below $1 \log \mathrm{cfu} / \mathrm{g}$ whereas a combination of $0.9 \%$ oregano $\mathrm{EO}$ and nisin at 500 or 1000 $\mathrm{IU} / \mathrm{g}$ showed a bactericidal effect. The addition of $0.6 \%$ or $0.9 \% \mathrm{EO}$ was found to be organoleptically acceptable also. EOs have also been applied for the elimination of Salmonella on fresh tomatoes. Gündüz et al. (2010) tested the antimicrobial potential of essential oil extracts on tomatoes. The tomatoes were inoculated with the nalidixic acid resistant strain of Salmonella Typhimurium ATCC 13311 and treated for 5-20 min with water extracts of sumac or oregano oil. Tomatoes treated with $100 \mathrm{ppm}$ oregano or $4 \%$ sumac extract resulted in 2.78 and $2.38 \mathrm{log}$ reduction, respectively. Hayouni et al. (2008) studied the antimicrobial effect of extracts from Salvia officinalis L. and berries of Schinus molle $\mathrm{L}$ against $S$. anatum or $S$. Enteritidis inoculated on minced beef meat. Concentrations in the range of $0.02-0.1 \%$ showed bacteriostatic effect against both the bacteria by the 
extracts from S. officinalis and S. molle for over 15 days. In case of S. molle, the bacteriostatic effect was seen up to a concentration of $1 \%$. At concentrations higher than $1.5 \%$ for S. officinalis and $2 \%$ for S. molle, immediate bactericidal effect was observed with a $2.6 \log \mathrm{cfu} / \mathrm{g}$ reduction at $1.5 \%$ S. officinalis and $1 \log \mathrm{cfu} / \mathrm{g}$ at $2 \%$ S. molle. However, sensory analysis of meat containing more than $2 \%$ of S. molle and $1.5 \%$ of S. officinalis showed a distinguished effect on the flavour and taste. In order to reduce the amount of EO being used, combinations of $\mathrm{EO}$ with $\mathrm{NaCl}$ were studied. The use of $0.1 \%$ or $1.5 \% \mathrm{~S}$. officinalis with $6 \%$ or $4 \% \mathrm{NaCl}$ or $0.1 \%$ or $1.5 \%$ S. molle with 4 or $8 \%$ Nacl could effectively eliminate S. anatum from refrigerated raw beef (Hayouni et al., 2008). The positive effect of spices on the inactivation of $S$. Typhimurium DT104 was observed when in direct contact, however, the activity reduced when added to food system such as ground beef (Uhart et al., 2006). Utilization of packaging materials containing these antimicrobial compounds is also becoming an attractive option in the food industry. However, a major limitation in using the EO in foods is the effect they have on the sensory properties of foods. At times, the concentration required to show the antimicrobial effect can surpass the organoleptically levels resulting in alteration in the flavor of foods.

\section{Hurdle technology or synergism}

Hurdle approach or the process of using multiple technologies is an effective approach to improve microbial decontamination in comparison to that of a single technology alone. Deliberate and intelligent combination of preservative treatments can help in maintaining the quality of food and delivering almost similar levels of microbial destruction as conventional methods alone. At the same time it warranties to counteract the negative effect of individual technologies on food quality. The choice of hurdles will strongly depend on the type of food it is being applied to in addition to the mode of inactivation. Potential synergistic effects among different technologies have been reported to be more effective than individual technologies applied alone. The outer membrane of gram negative cells prevents the entry of hydrophobic compounds. A combined treatment of heat and irradiation can result in sub-lethal injury to the cells. The sublethally injured cells can be more vulnerable to attack by antimicrobial compounds thereby reducing the dose of each individual technique.

For instance, combined effect of UV-C $\left(0.5 \mathrm{~J} / \mathrm{cm}^{2}\right)$ and potassium lactate, lauric arginate ester and sodium diacetate (FDA approved) resulted in a 3.6-4.1 log reduction of Salmonella, L. monocytogenes and Staphylococcus aureus on the surface of frankfurters (12 weeks storage at $10{ }^{\circ} \mathrm{C}$ ). In addition, UV-C and antimicrobials had no significant impact on frankfurter color or texture (Sommers et al., 2010). Amiali et al. (2007) studied the synergistic effects of temperature, treatment time and electric field strength on inactivation of $S$. Enteritidis and Escherichia coli O157:H7 in egg yolk. A 5 log reduction in the population of E. coli O157:H7 and S. enteritidis was observed at an electric field of $30 \mathrm{kV} \mathrm{cm}^{-1}$ and $40{ }^{\circ} \mathrm{C}$.

Exposure of egg shells contaminated with $S$. Enteritidis with UV radiation (1,500 to 2,500 $\left.\mu \mathrm{W} / \mathrm{cm}^{2}\right)$ followed by ozone $\left(5 \mathrm{lb} / \mathrm{in}^{2}\right.$ gauge for $1 \mathrm{~min}$ ) resulted in an inactivation of 4.6 logs or more in a total treatment time of 2 min (Roriguez-Romo and Yousef, 2005). Although the individual treatments resulted in similar reductions, however exposure time and pressure were comparatively higher. Combined treatment of lactic and acetic acid with super critical $\mathrm{CO}_{2}$ resulted in $2.33 \mathrm{log} \mathrm{cfu} / \mathrm{cm}^{2}$ reduction in $S$. Typhimurium in fresh pork which was higher as compared to these treatments being applied individually (Choi et al., 2009b). 
Application of PEF $(25 \mathrm{kV} / \mathrm{cm}, 250 \mu \mathrm{s}$ in pulses of $2.12 \mu \mathrm{s})$ followed by heat treatment at $55^{\circ} \mathrm{C}$ for $3.5 \mathrm{~min}$ increased the inactivation of Salmonella Enteritidis inoculated into liquid whole egg from 1 logs to 4.3 logs (Hermawan et al., 2004). The combination treatment had no effect on the color, $\mathrm{pH}$, viscosity and brix of the treated samples and had a longer shelf life in comparison to heat treated samples.

High pressure applied in combination with other agents such as heat or antimicrobial agents can be effectively used to increase microbial inactivation. Individual and combined effects of HPP and nisin treatment on relative resistance, viability and cellular components on S. Enteritidis (strains: FDA and OSU 799) was evaluated in culture media. High pressure up to $200 \mathrm{MPa}$ and nisin $(200 \mathrm{IU} / \mathrm{ml})$ when applied separately did not have any effect on the viability of either strain. However, application of high pressure (500 $\mathrm{MPa}$ ) or a combination of nisin with a pressure of 350MPa (OSU 799 strain) and $400 \mathrm{MPa}$ (FDA strain) resulted in an $8 \log$ reduction (Lee and Kaletunç, 2010). Penetration of nisin into the cells was assisted by the pressure and thereafter the additive effect of two hurdles resulted in inactivation to be achieved at a lower value than when the technique was applied separately. Viedma et al. (2008) studied the synergistic effects of antimicrobial peptide enterocin AS-48 and high-intensity-PEF treatment $(35 \mathrm{kV} / \mathrm{cm}, 150 \mathrm{~Hz}, 4 \mu \mathrm{s}$ and bipolar mode) on the inhibition of $S$. enterica CECT 915 in apple juice. A combination of high intensity PEF $(1000 \mu \mathrm{s})$ and AS-48 $(60 \mu \mathrm{g} / \mathrm{ml})$ and a treatment temperature of $40{ }^{\circ} \mathrm{C}$ resulted in $4.5 \log$ reduction. The sequence of the synergistic treatments was an important factor as the inhibition was observed only when HIPEF was applied in the presence of previously-added bacteriocin. Since both, enterocin AS-48 and high pressure PEF, act on the bacterial cytoplasmic membrane, synergism between them could be a result of enhanced permeability of bacterial cytoplasmic membrane.

\section{Conclusion}

With the rise of the concept of "green consumerism", meeting the consumer demand for nutritious and fresh food in addition to providing food safety has increased interest in non thermal preservation methods. The literature described herein gives an account of some of the non-thermal methods used for the elimination of Salmonella from foods. Considering the wide range of conditions under which Salmonella can easily grow, it is imperative to apply a combination of intervention technologies. With the advent of these novel methods of food preservation, it is hoped that issues of spoilage and contamination of food products, not only with Salmonella spp. but also with many other food spoilage or pathogenic microorganisms could be effectively controlled. Besides, a major impediment in the acceptance of foods processed by these emerging technologies is a lack of information among the consumers. Thus, it is very important to provide proper knowledge to the consumers regarding the benefits of these technologies as a means of food preservation.

\section{References}

Allende, A., McEvoy, J.L., Luo, Y., Artés, F., \& Wang, C.Y. (2006). Effectiveness of two-sided UV-C treatment in inhibiting natural microflora and extending the shelf-life of minimally processed 'Red Oak Leaf' lettuce. Food Microbiology, Vol. 23, No. 3, (May 2006), pp. 241-249, ISSN 0740-0020 
Amiali, M., Ngadi, M.O., Smith, J.P., \& Raghavan, G.S.V. (2007). Synergistic effect of temperature and pulsed electric field on inactivation of Escherichia coli O157:H7 and Salmonella enteritidis in liquid egg yolk. Journal of Food Engineering, Vol. 79, No. 2, (March 2007), pp. 689-694, ISSN 0260-8774.

Angsupanich K., \& Ledward, D.A. (1998). High pressure treatment effects on cod (Gadus morhua) muscle. Food Chemistry, Vol. 63, No. 1, (September 1998), pp. 39-50, ISSN 0308-8146

Barbosa-Canovas, G.V., Pierson, M.D., Zhang, Q.H., \& Schaffner, D.W. (2001). Pulsed electric fields. Journal of Food Science, pp. 65-79 Supplement, ISSN 1750-3841

Bouwknegt, M., Dam-Deisz, W.D.C., Schouten, J.M., Wannet, W.J.B., Van Pelt, W., Visser, G., van de Giessen, A. W., Surveillance of zoonotic bacteria in farm animals in the Netherlands (2003) Results from January 1998 until December 2000. (RIVM report 285859013, available from www.rivm.nl) Accessed on 2 July 2011, http://www.rivm.nl/bibliotheek/rapporten/285859013.pdf

Bull, M.K., Zerdin, K., Howe, E., Goicoechea, D., Paramanandhan, P., Stockman, R., Sellahewa, J., Szabo, S.A., Johnson, R.L., \& Stewart, C.M. (2004). The effect of high pressure processing on the microbial, physical and chemical properties of Valencia and Navel orange juice. Innovative Food Science and Emerging Technologies, Vol. 5, No. 2, (June 2004), pp. 135-149, ISSN 1466-8564

Burt, S.A., Fledderman, M.J., Haagsman, H.P., van Knapen, F., \& Veldhuizen, E.J.A. (2007). Inhibition of Salmonella enterica serotype Enteritidis on agar and raw chicken by carvacrol vapour. International Journal of Food Microbiology, Vol. 119, No. 3, (November 2007), pp. 346-350, ISSN 0168-1605

Careaga, M., Fernández, E., Dorantes, L., Mota, L., Jaramillo, M.E., \& Hernandez-Sanchez, H. (2003). Antibacterial activity of Capsicum extract against Salmonella typhimurium and Pseudomonas aeruginosa inoculated in raw beef meat. International Journal of Food Microbiology, Vol. 83, No. 3, (June 2003), pp. 331-335, ISSN 0168-1605

Cheah, P.B., \& Ledward, D.A. (1996). High pressure effects on lipid oxidation in minced pork. Meat Science, Vol. 43, No. 2, (June 1996), pp. 123-134, ISSN 0309-1740

Chen, H., Guan, D., \& Hoover, D.G. (2006). Sensitivities of food-borne pathogens to pressure changes. Journal of Food Protection, Vol. 69, No. 1, (January 2006), pp. 130-136, ISSN 0362-028X

Choi, Y.M., Bae, Y.Y., Kim, K.H., Kim, B.C., \& Rhee, M.S. (2009a). Effects of supercritical carbon dioxide treatment against generic Escherichia coli, Listeria monocytogenes, Salmonella typhimurium, and E. coli O157:H7 in marinades and marinated pork. Meat Science, Vol. 82, No. 4, (August 2009), pp. 419-424, ISSN 0309-1740

Choi, Y.M., Kim, O.Y., Kim, K.H., Kim, B.C., \& Rhee, M.S. (2009b). Combined effect of organic acids and supercritical carbon dioxide treatments against nonpathogenic Escherichia coli, Listeria monocytogenes, Salmonella typhimurium and E. coli O157:H7 in fresh pork. Letters in Applied Microbiology, Vol. 49, No. 4, (October 2009), pp. 510515, ISSN 0266-8254.

Chun, H.H., Kim, J.Y., Chung, K.S., Won, M., \& Song, K.B. (2009). Inactivation kinetics of Listeria monocytogenes, Salmonella enterica serovar Typhimurium, and Campylobacter 
jejuni in ready-to-eat sliced ham using UV-C irradiation. Meat Science, Vol. 83, No. 4, (December 2009), pp. 599-603, ISSN 0309-1740

Chun, H.H., Kim, J.Y., Lee, B.D., Yu, D.J., \& Song, K.B. (2010). Effect of UV-C irradiation on the inactivation of inoculated pathogens and quality of chicken breasts during storage. Food Control, Vol. 21, No. 3, (March 2010), pp. 276-280, ISSN 0956-7135

de Souza, P.M., \& Fernández, A. (2011). Effects of UV-C on physicochemical quality attributes and Salmonella enteritidis inactivation in liquid egg products. Food Control, Vol. 22, No. 8, (August 2011), pp. 1385-1392, ISSN: 0956-7135

Erkmen, O. (2000). Inactivation of Salmonella typhimurium by high pressure carbon dioxide. Food Microbiology, Vol. 17, No. 2, (April 2000), pp. 225-232, ISSN: 0740-0020

Erkmen, O., \& Karaman, H., (2001). Kinetic studies on the high pressure carbon dioxide inactivation of Salmonella typhimurium. Journal of Food Engineering, Vol. 50, No. 1, (October 2001), pp. 25-28, ISSN 0260-8774

EFSA (2009). The community summary report on food-borne outbreaks in the European Union in 2007. ESFA Journal, (available at efsa.europa.eu), Accessed on 29 June 2011, http://www.efsa.europa.eu/en/efsajournal/pub/271r.htm

EFSA-ECDC, (2007). EFSA-ECDC report for 2007: Salmonella remains most common cause of food-borne outbreaks, (available at efsa.europa.eu), Accessed on 25 June 2011, http://www.efsa.europa.eu/en/press/news/zoonoses090506.htm

Escriu, R., \& Mor-Mur, M. (2009). Role of quantity and quality of fat in meat models inoculated with Listeria innocua or Salmonella Typhimurium treated by high pressure and refrigerated stored. Food Microbiology, Vol. 26, No. 8, (December 2009), pp. 834840, ISSN 0740-0020

FDA, 2001. Food and Drug Administration (FDA) final rule-66 FR 6137, Hazard analysis and critical control point (HACCP) procedures for the safe and sanity processing of juice. Federal Register, date of access 10 July 2011

http://www.fda.gov/Food/FoodSafety/HazardAnalysisCriticalControlPointsHA $\mathrm{CCP} /$ JuiceHACCP/ucm073594.htm

Goodridge, L.D., Willford, J., \& Kalchayanand, N. (2006). Destruction of Salmonella Enteriditis inoculated onto raw almonds by high hydrostatic pressure. Food Research International, Vol. 39, No. 4, (May 2006), pp. 408-412, ISSN 0963-9969

Govaris, A., Solomakos, N., Pexara, N., \& Chatzopoulou, P.S. (2010). The antimicrobial effect of oregano essential oil, nisin and their combination against Salmonella Enteritidis in minced sheep meat during refrigerated storage. International Journal of Food Microbiology, Vol. 137, No. 2-3, (February 2010), pp. 175-180, ISSN 01681605.

Gündüz, G.T., Gönül, S.A., \& Karapinar, M. (2010). Efficacy of sumac and oregano in the inactivation of Salmonella Typhimurium on tomatoes. International Journal of Food Microbiology, Vol. 141, No.1-2, (June 2010), pp. 39-44, ISSN 0168-1605

Gupta, S., Cox, S., Rajauria, G., Jaiswal, A.K., \& Abu-Ghannam, N. (2011). Growth inhibition of common food spoilage and pathogenic micro-organisms in the presence of brown seaweed extracts. Food and Bioprocess Technology, (DOI: 10.1007/s11947-0100502-6), ISSN 1935-5130 
Hayouni, E.A., Chraief, I., Abedrabba, M., Bouix, M., Leveau, J.Y., Mohammed, M., \& Hamdi, M. (2008). Tunisian Salvia officinalis L. and Schinus molle L. essential oils: Their chemical compositions and their preservative effects against Salmonella inoculated in minced beef meat. International Journal of Food Microbiology, Vol. 125, No. 3, (July 2008), pp. 242-251, ISSN 0168-1605

Hermawan, N., Evrendilek, G.A., Dantzer, W.R., Zhang, Q.H., \& Richter, E.R. (2004). Pulsed electric field treatment of liquid whole egg inoculated with Salmonella enteritidis. Journal of Food Safety, Vol. 24, No. 1, (April 2004), pp. 71-85, ISSN 0149-6085

Hong, Y.H., Park, J.Y., Park, J.H., Chung, M.S., Kwon, K.S., Chung, K., Won, M., \& Song, K.B. (2008). Inactivation of Enterobacter sakazakii, Bacillus cereus, and Salmonella typhimurium in powdered weaning food by electron-beam irradiation. Radiation Physics and Chemistry, Vol. 77, No. 9, (September 2008), pp. 1097-1100, ISSN: 0969806X

Hvizdzak, A.L., Beamer, S., Jaczynski, J., \& Matak, K.E. (2010). Use of electron beam radiation for the reduction of Salmonella enteric serovars typhimurium and Tennessee in peanut butter. Journal of Food Protection, Vol. 73, No. 2, (February 2010), pp. 353-357, ISSN 0362-028X

Jaiswal, A.K., Gupta, S., Abu-Ghannam, N., \& Cox, S. (2011). Application of Baranyi function to model the antibacterial properties of solvent extract from Irish York cabbage against food spoilage and pathogenic bacteria. Food Science and Technology International, (DOI 10.1177/1082013210399667), ISSN 1532-1738

Karapinar, M., \& Sengun, I.Y. (2007). Antimicrobial effect of koruk (unripe grape-Vitis vinifera) juice against Salmonella typhimurium on salad vegetables. Food Control, Vol. 18, No. 6, (June 2007), pp. 702-706, ISSN 0956-7135

Kim, Y.H., Nam, K.C., \& Ahn, D.U. (2002). Color, oxidation-reduction potential, and gas production of irradiated meat from different animal species. Journal of Food Science, Vol. 67, No. 5, (June 2002), pp. 1692-1695, ISSN 1750-3841

Kim, S.R., Rhee, M.S., Kim, B.C., Lee, H.J., \&Kim, K.H. (2007). Modeling of the inactivation of Salmonella typhimurium by supercritical carbon dioxide in physiological saline and phosphate-buffered saline. Journal of Microbiological Methods, Vol. 70, No. 1, (July 2007), pp. 132-141, ISSN 0167-7012

Kincal, D., Hill, W.S., Balaban, M.O., Portier, K.M., Wei, C.I., \& Marshall, M.R. (2005). A continuous high pressure carbon dioxide system for microbial reduction in orange juice. Journal of Food Science, Vol. 70, No. 5, (June 2005), pp. M249-M254, ISSN 17503841

Lee, J., \& Kaletunç, J. (2010). Inactivation of Salmonella Enteritidis strains by combination of high hydrostatic pressure and nisin. International Journal of Food Microbiology, Vol. 140, No. 1, (May 2010), pp. 49-56, ISSN 0168-1605

Liang, Z., Mittal, G.S., \& Griffiths, M.W. (2002). Inactivation of Salmonella Typhimurium in orange juice containing antimicrobial agents by pulsed electric field. Journal of Food Protection, Vol. 65, No. 7, (July 2002), pp. 1081-1087, ISSN 0362-028X

Liao, H., Kong, X., Zhang, Z., Liao, X., \&, Hu, X. (2010). Modeling the inactivation of Salmonella typhimurium by dense phase carbon dioxide in carrot juice. Food Microbiology, Vol. 27, No. 1, (February 2010), pp. 94-100, ISSN 0740-0020 
Ma, H.J., Ledward, D.A., Zamri, A.I., Frazier, R.A., \& Zhou, G.H. (2007). Effects of high pressure / thermal treatment on lipid oxidation in beef \& chicken muscle. Food Chemistry, Vol. 104, No. 4, (2007), pp. 1575-1579, ISSN 0308-8146

Mahmoud, B.S.M. (2009). Effect of X-ray treatments on inoculated Escherichia coli O157:H7, Salmonella enterica, Shigella flexneri and Vibrio parahaemolyticus in ready-to-eat shrimp. Food Microbiology, Vol. 26, No. 8, (December 2009), pp. 860-864, ISSN 07400020

Mahmoud, B.S.M., Bachman, G., \& Linton, R.H. (2010). Inactivation of Escherichia coli O157:H7, Listeria monocytogenes, Salmonella enterica and Shigella flexneri on spinach leaves by X-ray. Food Microbiology, Vol. 27, No. 1 (February 2010), pp. 24-28, ISSN 0740-0020

Mahmoud, B.S.M. (2010). The effects of X-ray radiation on Escherichia coli O157:H7, Listeria monocytogenes, Salmonella enterica and Shigella flexneri inoculated on whole Roma tomatoes. Food microbiology, Vol. 27, No. 8, (December 2010), pp. 1057-1063, ISSN 0740-0020

Maitland, J.E., Boyer, R.R., Eifert, J.D., \& Williams, R.C. (2011). High hydrostatic pressure processing reduces Salmonella enterica serovars in diced and whole tomatoes. International Journal of Food Microbiology, doi:10.1016/j.ijfoodmicro.2011.05.024, ISSN 0168-1605

Martins, C.G., Behrens, J.H., Destro, M.T., Franco, B.D.G.M., Vizeu, D.M., Hutzler, B., \& Landgraf, M. (2004). Gamma radiation in the reduction of Salmonella spp. inoculated on minimally processed watercress (Nasturtium officinalis). Radiation Physics and Chemistry, Vol. 71, No. 1-2, (September -October 2004), pp. 89-93, ISSN 0969-806X

McArdle, R.A., Marcos, B., Kerry, J.P., \& Mullen, A.M. (2011). Influence of HPP conditions on selected beef quality attributes and their stability during chilled storage. Meat Science, Vol. 87, No. 3, (March 2011), pp. 274-281, ISSN 0309-1740

Monfort, S., Gayán, E., Saldaña, G., Puértolas, E., Condón, S., Raso, J., \& Álvarez, I. (2010). Inactivation of Salmonella Typhimurium and Staphylococcus aureus by pulsed electric fields in liquid whole egg. Innovative Food Science and Emerging Technologies, Vol. 11, No. 2, (April 2010), pp. 306-313, ISSN 1466-8564

Mosqueda-Melgar, J., Raybaudi-Massilia, R.M., \& Martín-Belloso, O. (2007). Influence of treatment time and pulse frequency on Salmonella Enteritidis, Escherichia coli and Listeria monocytogenes populations inoculated in melon and watermelon juices treated by pulsed electric fields. International Journal of Food Microbiology. Vol. 117, No.2, (June 2007), pp.192-200, ISSN 0168-1605

Ohene-Adjei, S., Bertol, T., Hyung, Y., Ellis, M., McKeith, F.K., \& Brewer, M.S. (2004). Effect of vitamin $\mathrm{E}$, low dose irradiation and display time on the quality of pork. Meat Science, Vol. 68, No. 1, (September 2004), pp. 19-26

Park, J.G., Yoon, Y., Park, J.N., Han, I.J., Song, B.S., Kim, J.H., Kim, W.G., Hwang, H.J., Han, S.B., \& Lee, J.W. (2010). Effects of gamma irradiation and electron beam irradiation on quality, sensory, and bacterial populations in beef sausage patties. Meat Science, Vol. 85, No.2, (June 2010), pp. 368-372, ISSN 0309-1740 
Prakash, A., Lim, F.T., Duong, C., Caporaso, F., \& Foley, D. (2010). The effects of ionizing irradiation on Salmonella inoculated on almonds and changes in sensory properties. Radiation Physics and Chemistry, Vol. 79, No. 4, (April 2010), pp. 502-506, ISSN 0969806X

Risco, S.A.D. (2009). Risk factors influencing the growth and survival of Salmonella on poultry products. Ph.D. thesis, Rutgers The State University of New Jersey - New Brunswick. 140 pages

Roriguez-Romo, L.A., \& Yousef, A.E. (2005). Inactivation of Salmonella enteric serovar enteritidis on shell eggs by ozone and UV radiation. Journal of Food Protection, Vol. 68, No. 4, (April 2005), pp. 711-717, ISSN 0362-028X

Sommers, C. H., Scullen, O. J., \& Sites, J. E. (2010). Inactivation of foodborne pathogens on frankfurters using ultraviolet light and GRAS antimicrobials. Journal of Food Safety, Vol. 30, No. 3, (August 2010), pp. 668-678, ISSN 0149-6085.

Song, H.J., Lee, J.H., \& Song, K.B. (2011). Effects of irradiation and fumaric acid treatment on the inactivation of Listeria monocytogenes and Salmonella typhimurium inoculated on sliced ham. Radiation Physics and Chemistry, doi:10.1016/j.radphyschem.2011.06.012, ISSN 0969-806X

Tahergorabi, R., Matak, K.E., \& Jaczynski, J. (2011). Application of electron beam to inactivate Salmonella in food: Recent developments. Food Research International, doi:10.1016/j.foodres.2011.02.003, ISSN 0963-9969

Teo, A.Y., Ravishankar, S., \& Sizer, C.E. (2001). Effect of low-temperature, high-pressure treatment on the survival of Escherichia coli O157:H7 and Salmonella in unpasteurised fruit juices. Journal of Food Protection, Vol. 64, No. 8, (August 2001), pp. 1122-1127, ISSN 0362-028X

Tesfai, A.T., Beamer, S.K., Matak, K.E., \& Jaczynski, J. (2011). Microbial radio-resistance of Salmonella Typhimurium in egg increases due to repetitive irradiation with electron beam. Radiation Physics and Chemistry, Vol. 80, No. 4, (April 2011), pp. 591596, ISSN 0969-806X

Uhart, M., Maks, N., \& Ravishankar, S. (2006). Effect of spices on growth and survival of Salmonella typhimurium DT 104 in ground beef stored at 4 and $8{ }^{\circ} \mathrm{C}$. Journal of Food Safety, Vol. 26, No. 2, (May 2006), pp. 115-125, ISSN 0149-6085.

USFDA, (2007). US Food and Drug Administration, 2007 (http://www.fda.gov/Food/FoodIngredientsPackaging/IrradiatedFoodPackagin g/ucm110564.htm\#authors) Accessed on 15 June 2011

Viedma, P.M., López, A.S., Omar, N.B., Abriouel, H., López, S.L., Valdivia, E., Belloso, O.M., \& Gálvez, A. (2008). Enhanced bactericidal effect of enterocin AS-48 in combination with high-intensity pulsed-electric field treatment against Salmonella enterica in apple juice. International Journal Food Microbiology, Vol. 128, No. 2, (December 2008), pp. 244-249, ISSN 0168-1605

Wei, C.I., Balaban, M.O., Fernando. S.Y., \& Peplow, A.J. (1991). Bacterial effect of high pressure $\mathrm{CO}_{2}$ treatment on foods spiked with Listeria and Salmonella. Journal of Food Protection, Vol. 54, (1991), pp. 189-193, ISSN 0362-028X

Whitney, B.M., Williams, R., Eifert, J., \& Marcy, J. (2007). High- pressure resistance variation of Escherichia coli O157:H7 strains and Salmonella serovars in tryptic soy broth, 
distilled water, and fruit juice. Journal of Food Protection, Vol. 70, No. 9, (September 2007), pp. 2078-2083, ISSN 0362-028X

Wouters, P., Álvarez, I., \&. Raso, J. (2001). Critical factors determining inactivation kinetics by pulsed electric field food processing. Trends in Food Science E Technology, Vol. 12, No. 3-4, (March 2001), pp. 112-121, ISSN 0924-2244

Xu, W., Qu, W., Huang, K., Guo, F., Yang, J., Zhao, H., \& Luo, Y.B. (2007). Antibacterial effect of Grapefruit Seed Extract on food-borne pathogens and its application in the preservation of minimally processed vegetables. Postharvest Biology and Technology, Vol. 45, No. 1, (July 2007), pp. 126-133, ISSN 0925-5214. 


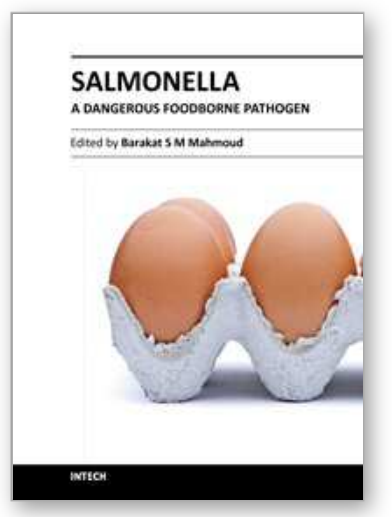

\author{
Salmonella - A Dangerous Foodborne Pathogen \\ Edited by Dr. Dr. Barakat S M Mahmoud
}

ISBN 978-953-307-782-6

Hard cover, 450 pages

Publisher InTech

Published online 20, January, 2012

Published in print edition January, 2012

More than 2,500 serotypes of Salmonella exist. However, only some of these serotypes have been frequently associated with food-borne illnesses. Salmonella is the second most dominant bacterial cause of food-borne gastroenteritis worldwide. Often, most people who suffer from Salmonella infections have temporary gastroenteritis, which usually does not require treatment. However, when infection becomes invasive, antimicrobial treatment is mandatory. Symptoms generally occur 8 to 72 hours after ingestion of the pathogen and can last 3 to 5 days. Children, the elderly, and immunocompromised individuals are the most susceptible to salmonellosis infections. The annual economic cost due to food-borne Salmonella infections in the United States alone is estimated at $\$ 2.4$ billion, with an estimated 1.4 million cases of salmonellosis and more than 500 deaths annually. This book contains nineteen chapters which cover a range of different topics, such as the role of foods in Salmonella infections, food-borne outbreaks caused by Salmonella, biofilm formation, antimicrobial drug resistance of Salmonella isolates, methods for controlling Salmonella in food, and Salmonella isolation and identification methods.

\title{
How to reference
}

In order to correctly reference this scholarly work, feel free to copy and paste the following:

Shilpi Gupta and Nissreen Abu-Ghannam (2012). Recent Advances in the Application of Non Thermal Methods for the Prevention of Salmonella in Foods, Salmonella - A Dangerous Foodborne Pathogen, Dr. Dr. Barakat S M Mahmoud (Ed.), ISBN: 978-953-307-782-6, InTech, Available from: http://www.intechopen.com/books/salmonella-a-dangerous-foodborne-pathogen/recent-advances-in-theapplication-of-non-thermal-methods-for-the-prevention-of-salmonella-in-foods

\section{INTECH}

open science | open minds

\section{InTech Europe}

University Campus STeP Ri

Slavka Krautzeka 83/A

51000 Rijeka, Croatia

Phone: +385 (51) 770447

Fax: +385 (51) 686166

www.intechopen.com

\section{InTech China}

Unit 405, Office Block, Hotel Equatorial Shanghai

No.65, Yan An Road (West), Shanghai, 200040, China

中国上海市延安西路65号上海国际贵都大饭店办公楼405单元

Phone: +86-21-62489820

Fax: +86-21-62489821 
(C) 2012 The Author(s). Licensee IntechOpen. This is an open access article distributed under the terms of the Creative Commons Attribution 3.0 License, which permits unrestricted use, distribution, and reproduction in any medium, provided the original work is properly cited. 